\title{
ANALISA DAN IMPLEMENTASI ASSOCIATION RULE DENGAN ALGORITMA FP-GROWTH DALAM SELEKSI PEMBELIAN TANAH LIAT (STUDI KASUS DI PT. ANVEVE ISMI BERJAYA)
}

\author{
Dio Prima Mulya ${ }^{1)}$
}

1) Magister Ilmu Komputer, Universitas Putra Indonesia, Padang email: dio.prima.mulya.dp@gmail.com

\begin{abstract}
Data Mining aims to draw abstract knowledge of a big database.Data Mining also known as Knowledge Discovery Database. FP-Growth algorithm is one of the very popular algorithms in finding frequent itemset in finding the rule of a large data base. Association rule used to find patterns in market basket analysis. Steps in the process of association rule mining is confidence and support. Clay formed from the weathering of silica by carbonic acid and partly generated by geothermal activity. In this study using FP-Growth Algorithm in purchasing decisions withdrawal clay by PT. ISMI ANVEVE BERJAYA.
\end{abstract}

Keyword: Knowledge Discovery Database, Data Mining, Association Rule, Fp-Growth, frequent itemset.

\section{Abstrak}

Data Mining bertujuan untuk menarik pengetahuan abstrak dari sebuah database yang besar.Data Mining juga dikenal sebagai Knowledge Discovery Database. Algoritma FPGrowth adalah salah satu algoritma yang sangat populer dalam mencari frequent itemset dalam menemukan rule dari basis data yang besar. Association rule digunakan dalam menemukan pola dalam market basket analysis. Langkah dalam proses association rule mining yaitu confidence dan support. Tanah liat terbentuk dari pelapukan silika oleh asam karbonat dan sebagian lagi dihasilkan oleh aktifitas panas bumi. Dalam penelitian ini menggunakan Algoritma FP-Growth dalam penarikan keputusan pembelian tanah liat oleh PT. ANVEVE ISMI BERJAYA.

Kata kunci : Knowledge Discovery Database, Data Mining, Association Rule, Fp-Growth, frequent itemset.

\section{Pendahuluan}

Penyajian informasi tidak sepadan dengan kebutuhan informasi yang sangat tinggi. Salah satu cara penggalian informasi dari sekumpulan database yang besar yaitu Data Mining. Tujuan dari Data Mining adalah untuk menarik pengetahuan abstrak dari sebuah database yang besar.

Hal terpenting dalam teknik Data Mining adalah aturan untuk menemukan pola frekuensi tinggi antar himpunan itemset yang disebut fungsi association rules(aturan asosiasi). Langkah-langkah dalam proses association rule mining, yaitu confidence dan support.

\section{METODE}

2.1 Knowledge Discovery in Database

Knowladge Discovery in Database (KDD) didefinisikan sebagai ekstraksi informasi potensial, implisit dan tidak dikenal dari sekumpulan data, Proses Knowladge Discovery in Database melibatkan hasil proses Data Mining (proses pengekstrak kecenderungan suatu pola data), kemudian mengubah hasilnya secara akurat menjadi informasi yang mudah dipahami (Tampubolon et al, 2013).

KDD terdiri dari tiga proses utama yaitu (anis Kurniawati, 2014). 
a. Preprocessing

Preprocessing dilakikan terhadap data sebelum algoritma Data Mining diaplikasikan. Proses ini meliputi data cleaning, intergrasi, seleksi dan transformasi.

b. Data Mining

Proses utama dalam KDD adalah proses Data Mining, dalam proses ini algoritmaalgoritma Data Mining diaplikasikan untuk mendapatkan pengetahuan dari sumber data.

c. Post processing

Hasil yang diperoleh dari proses Data Mining selanjutnya akan dievaluasi pada post processing.

Menurut Han dan Kamber (2012) Knowladge discovery sebagai sebuah proses yang digambarkan pada gambar 2.1, dan terdiri atas runtunan iterative dari langkahlangkah berikut :

a. Data cleaning (untuk membuang noise dan data yang tidak konsisten).

b. Data integration (beragam sumber data digabungkan).

c. Data selection (data yang relevan untuk dianalisa di retrive dari database)

d. Data transformation (dimana data diubah atau dikonsolidasi ke dalam bentuk yang sesuai untuk pertambangan misalnya dengan melakukan ringkasan atau operasi agregasi).

e. Data Mining (sebuah proses esensi dimana metode cerdas diterapkan untuk mengekstraksi pola-pola data).

f. Pattern evaluation (mengidentifikasi pola yang benar menarik merepresentasikan dasar pengetahuan pada beberapa ukuran menarik).

g. Knowledge presentation (teknik representasi visalisasi dan pengetahuan digunakan untuk memperlihatkan pengetahuan yang telah ditambang kepada pengguna).

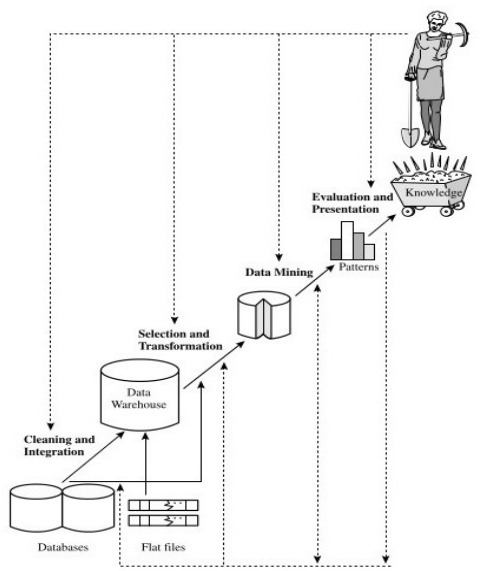

\subsection{Data Mining}

Data Mining adalah penambangan atau penemuan informasi baru dengan mencari pola atau aturan tertentu dari sejumlah data yang sangat besar (Beta et al dalam jurnal Sarjon Defit, 2013).

\subsubsection{Pengelompokan Data Mining}

Data Mining dibagi menjadi beberapa kelompok berdasarkan tugas yang dapat dilakukan, yaitu (Kusrini dan Emha Taufiq Luthfi, 2009 dalam Tampubolon, saragih, reza, 2013):

a. Deskripsi

Proses pencarian data untuk menggambarkan pola dan kecenderungan yang terdapat dalam data.

b. Estimasi

Estimasi hampir sama dengan klasifikasi, kecuali variabel target estimasi lebih kearah numerik dari pada kearah kategori

c. Prediksi Prediksi hampir sama dengan klasifikasi dan estimasi, kecuali bahwa dalam prediksi nilai dari hasil akan ada dimasa mendatang.

d. Klasifikasi

Dalam klasifikasi, terdapat target variabel kategori. 
e. Clustering (Pengklusteran)

Kluster adalah kumpulan record-record yang memiliki kemiripan satu dengan yang lainnya dan memiliki ketidakmiripan dengan record-record dalam kluster lain.

f. Asosiasi

Tugas asosiasi dalam
Data Mining adalah
menemukan attribut yang
muncul dalam satu waktu.

\subsubsection{Tahapan Dalam Data Mining}

Menurut Feen Lee \& Juan Santana (2010:37-40) langkahlangkah yang dibutuhkan untuk mengerjakan implementasi Data Mining sebagai berikut (Tampubolon et al, 2013):

a. Tahap pertama : Precise statement of the problem (mendefinisikan

permasalahan yang ingin diketahui). Tugas dasar yang menjadi dasar algoritma Data Mining adalah klasifikasi, regresi, segmantasi, asosiasi dan sequence analisis.

b. Tahap kedua : Initial Exploration (mempersiapkan data yang menjadi sumber untuk Data Mining termaksud data "cleaning" untuk mempelajari polanya). Setelah menemukan defenisi masalah, langkah berikutnya adalah mencari data yang mendukung defenisi masalah. Menentukan porsi data yang digunakan men-training Data Mining berdasar algoritma Data Mining yang telah dibuat. Setelah persiapan data selesai dilakukan, langkah berikutnya adalah memberikan sebagian data kedalam algoritma Data Mining.

c. Tahap ketiga : Model building and validation. Validasi apakah Data Mining memberikan prediksi yang akurat. Setelah training data selesai dilakukan, Data Mining tersebut perlu di-“uji”" atau di-validasi keakuratannya terhadap data testing.

d. Tahap ke-empat: Deployment. Tahap ini memilih aplikasi yang tepat terhadap Data Mining untuk membuat prediksi.

Berdasarkan beberapa pengertian diatas dapat ditarik kesimpulan bahwa Data Mining adalah sebuah analisa dari observasi data dalam jumlah besar untuk menemukan hubungan yang tidak diketahu sebelumnya dan metode baru untuk meringkas data agar mudah dipahami serta kegunaan untuk pemilik data.

\subsection{Association Rule (Aturan Asosiasi)}

Beberapa pengertian Association rule yang berhasil penulis himpun dari beberapa literatur adalah sebagai berikut:

a. Association rule adalah salah satu metode yang bertujuan mencari pola yang sering muncul diantara banyak transaksi, dimana setiap transaksi terdiri dari beberapa item (Sarjon Defit, 2013).

b. Association rule adalah salah satu teknik Data Mining yang mana diharapkan untuk menjadi aplikasi yang sangat bermanfaat (D. Magdelene Delighta Angeline, 2013).

c. Menurut amirudin et al (2007) Analisis asosiasi atau association rule mining adalah teknik Data Mining untuk menemukan aturan asosiasi antara kombinasi item (Tampubolon et al, 2013).

d. Menurut Goldie,G \& Dana, I.S (2012) Analisis asosiasi adalah teknik Data Mining untuk menemukan aturan asosiasi antara suatu kombinasi item (Sarjon Defit, 2013). 
e. Association rule merupakan salah satu bentuk pola yang dihasilkan oleh Data Mining. Association rule dapat digunakan untuk menemukan hubungan atau sebab akibat. Penting tidaknya suatu asosiasi dapat diketahui dengan dua tolak ukur, yaitu : support dan confidance. Support (nilai penunjang) adalah persentasi kombinasi item tersebut dalam database, sedangkan confidance (nilai kepastian) adalah kuatnya hubungan antar item dalam aturan asosiasi (Eka Novita Sari, 2013).

Association rule mempunyai bentuk LHS (Left Hand Shake) -> RHS (Right Hand Shake) dengan interpretasi juka setiap item dalam LHS dibeli maka sepertinya item dalam RHS juga dibeli. Dua pengukuran penting untuk sebuah rule adalah Support dan Confidace.

Support (s) didefinisikan sebagai presentasi record tehadap total record keseluruhan dalam database. Support dapat ditulis dalam rumus berikut :

\begin{tabular}{cc} 
Support & $(\mathrm{X})$ \\
& BanyaknyaX \\
\hline mla total transaksi dalam database $(D)$
\end{tabular}

Sementara nilai support dari 2 item dituliskan dalam rumus berikut:

$$
\text { Support }(\mathrm{X}, \mathrm{Y})=\mathrm{P}(\mathrm{X} \cap \mathrm{Y})
$$

Support (X,Y)

$\underline{\Sigma \text { Banyaknya transaksi } X \text { dan } Y}$

$$
\Sigma \text { Transaksi }
$$

Jadi jika misalnya Support sebuah item adalah $0,1 \%$ maknanya hanya 0,1 persen dari transaksi berisikan item ini.

Sementara Confidence (c) didefinisikan sebagai presentasi dari sejumlah transaksi yang berisikan $\mathrm{X} \cup \mathrm{Y}$ terhadap jumlah record keseluruhan yang mengandung $\mathrm{X}$. Confidence dapat dituliskan dalam rumus berikut :

$$
\text { Confidence }(\mathrm{X} \mid \mathrm{Y})=\frac{\text { Support }(X Y)}{\text { Support }(X)}
$$

Confidence merupakan ukuran kekuatan sebuah rule asosiasi. Jika kita anggap confidance $\mathrm{X}->\mathrm{Y}$ adalah $80 \%$, berarti sebanyak 80 persen transaksi yang mengandung $\mathrm{X}$ maka akan mengandung juka $\mathrm{Y}$.

Pada umumnya, menurut Han dan Kamber (2012:245) association rule mining dapat dilihat sebagai proses dua langkah, yaitu:

a. Temukan semua frequent itemsets, dengan pengertian setiap itemset ini akam muncul sesering sekurangnya minimum support (min-sup) yang telah ditentukan.

b. Hasilkan association rules yang kuat dari frequent itemsets: dengan pengertian rule-rule ini haruslah memenuhi minimum Support dan minimum Confidence.

\subsection{Langkah - Langkah Proses Aturan Asosiasi}

Menurut Eko Wahyu Tyas d (2008) proses aturan asosiasi terdiri dari beberapa tahap sebagai berikut (Tampubolon et al, 2013):

a. Sistem men-scan database untuk mendapatkan kandidat 1-itemset (himpunan item yang terdiri dari 1 item) dan menghitung nilai supportnya. Kemudian nilai supportnya tersebut dibandingkan dengan minimum support yang telah ditentukan, jika nilainya lebih besar atau sama dengan minimum support maka itemset tersebut termasuk dalam large itemset.

b. Itemset yang tidak termasuk dalam large itemset tidak diikutkan dlam iterasi selanjutnya (diprune).

c. Pada iterasi kedua sistem akan menggunakan hasil large itemset pada iterasi pertama (L1) untuk membentuk kandidat itemset kedua (L2). Pada iterasi selanjutnya sistem akan menggunakan hasil large itemset pada iterasi selanjutnya akakan 
menggunakan hasil large itemset pada iterasi sebelumnya (Lk-1) untuk membentuk kandidat itemset berikut (Lk). Sistem akan menggabungkan (join) Lk-1 dengan Lk-1 untuk mendapatkan Lk, seperti pada iterasi sebelumnya sistem akan menghapus (prune) kombinasi itemset yang tidak termasuk dalam large itemset.

d. Setelah dilakukan operasi join, maka pasangan itemset baru hasil proses join tersebut dihitung supportnya.

e. Proses pembentuk kandidat yang terdiri dari proses join dan prune akan terus dilakukan hingga himpunan kandidat itemsetnya null, atau sudah tidak ada lagi kandidat yang akan dibentuk.

f. Setelah itu, dari hasil frequent itemset tersebut dibentuk association rule yang memenuhi nilai support dan confidance yang telah ditentukan.

g. Pada pembentukan association rule, nilai yang sama dianngap sebagai satu nilai.

h. Association rule yang terbentuk harus memenuhi nilai minimum yang telah ditentukan.

i. Untuk setiap large itemset L, kita cari himpunan bagian $\mathrm{L}$ yang tidak kosong. Untuk setiap himpunan bagian tersebut, dihasilkan rule dengan bentuk aB(L-a) jika supportnya (L) dan supportnya (a) lebih besar dari minimum support.

\subsection{Algoritma FP-Growth}

Menurut Gunadi dan Sanuse (2012) FP-Growth adalah salah satu alternatif algoritma yang dapat digunakan untuk menentukan himpunan data yang paling sering muncul (frequent itemset) dalam sebuah kumpulan data. Fp-Growth menggunakan pendekatan yang berbeda dari paradigma yang digunakan pada algoritma apriori.

Menurut Ririanti (2014) FPGrowth adalah salah satu alternatif algoritma yang dapat digunakan untuk menentukan himpunan data yang paling sering muncul (frequent itemset) dalam sekumpulan data.

Algoritma FP-Growth merupakan pengembangan dari algoritma Apriori. FP-Growth adalah metode yang membangun sebuah struktur data yang sangat padat (FP-Tree) untuk kompres database transaksi asli.

Algoritma FP-Growth adalah metode yang efisien dimana mining dilakukan dengan struktur prefix-tree pada suatu itemset yang lengkap. Struktur tree menyimpan informasi tentang frequent pattern.

Algoritma ini dimulai dengan mengompresi database input, sehingga mengembangkan contoh dari sebuah frequent pattern tree. Database yang dikompresi kemudian dibagi menjadi beberapa database bersyarat. Dimana setiap database merepresentasikan sebuah unique frequent pattern. Oleh karena itu, biaya pencarian berkurang dan menawarkan selektivitas yang baik (Shivam et al, 2014).

Metode FP-Growth dibagi menjadi tiga tahapan utama, yaitu (Han et al, 2012):

1. Tahap pembangkitan conditional pattern base,

2. Tahapan pembangkitan conditional FP-Tree, dan

3. Tahapan pencarian frequent itemset.

\subsection{Tanah Liat (Clay)}

Tanah liat atau lempung adalah partikel mineral berkerangka dasar silikat yang berdiameter kurang dari 4 mikrometer. Lempung mengandung leburan silika dan/atau aluminium yang halus. Unsur-unsur ini, silikon, oksigen, dan aluminum adalah unsur yang paling banyak menyusun komposisi bumi. Lempung terbentuk 
dari proses pelapukan batuan silika oleh asam karbonat dan sebagian dihasilkan dari aktivitas panas bumi (S.O. Obaje, J.I. Omada, dan U.A. Dambatta, 2013).

\subsection{RAPIDMINER}

Rapidminer adalah sebuah alat Data Mining yang digunakan untuk menganalisis informasi web yang diakses. Rapidminer juga digunakan untuk penelitian, pendidikan, rapid prototyping, pengembangan aplikasi dan aplikasi industri. Proyek Rapidminer dimulai pada tahun 2001 oleh Ralf Klinkenberg, Ingo Mierswa, dan Simon Fischer di Artificial Intelligence Group of Katharina Morik di Dormund University of Technology.

Aplikasi yang merupakan Open Source ini termasuk data cleaning, data transformation, optimization, validation, and visualization. Visualisasinya dapat dilihat dalam bentuk scatter plot, bar, pie chart, dll. (M.Santhanakumar and C.Christopher Colombus, 2015).

\section{Analisa dan Hasil}

\subsection{Persiapan Data}

Dalam analisa ini penulis menganalisa dan mengelompokkan data sesuai dengan variabel yang dibutuhkan dalam menentukan pembelian tanah liat oleh PT. ANVEVE ISMI BERJAYA.

Pada Algoritma FP-Growth terbagi mejadi 3 tahapan, yaitu pembangkitan conditional pattern base, pembangkitan conditional FPTree, pencarian frequent itemset.

Data utama yang digunakan pada penelitian ini adalah data pembelian tanah liat oleh PT.ANVEVE ISMI BERJAYA pada bulan April sampai dengan Agustus tahun 2016 yang merupakan data yang akan dijadikan sampel dalam penerapan algoritma FP-Growth untuk penentuan pembelian tanah liat sesuai dengan pemenuhan kebutuhan perusahaaan.
Tabel 3.1 Produsen Tanah

\begin{tabular}{|c|l|}
\hline KODE & \multicolumn{1}{|c|}{ Produsen } \\
\hline A & Lantamal \\
\hline B & Bungus \\
\hline C & Gunung Sariak \\
\hline D & Savang Ibu \\
\hline E & Kuranji \\
\hline
\end{tabular}

Tabel 3.2 Kualitas Tanah

\begin{tabular}{|c|l|}
\hline KODE & \multicolumn{1}{|c|}{ KUALITAS TANAH } \\
\hline A1 & PRODUSEN A MINERAL TINGGI \\
\hline A2 & PRODUSEN A MINERAL SEDANG \\
\hline A3 & PRODUSEN A MINERAL RENDAH \\
\hline B1 & PRODUSEN B MINERAL TINGGI \\
\hline B2 & PRODUSEN B MINERAL SEDANG \\
\hline B3 & PRODUSEN B MINERAL RENDAH \\
\hline C1 & PRODUSEN C MINERAL TINGGI \\
\hline C2 & PRODUSEN C MINERAL SEDANG \\
\hline C3 & PRODUSEN C MINERAL RENDAH \\
\hline D1 & PRODUSEN D MINERAL TINGGI \\
\hline D2 & PRODUSEN D MINERAL SEDANG \\
\hline D3 & PRODUSEN D MINERAL RENDAH \\
\hline E1 & PRODUSEN E MINERAL TINGGI \\
\hline E2 & PRODUSEN E MINERAL SEDANG \\
\hline E3 & PRODUSEN E MINERAL RENDAH \\
\hline
\end{tabular}

Tabel 3.3 Data Pembelian Setelah dikonversi berdasarkan pemenuhan kebutuhan perusahaan

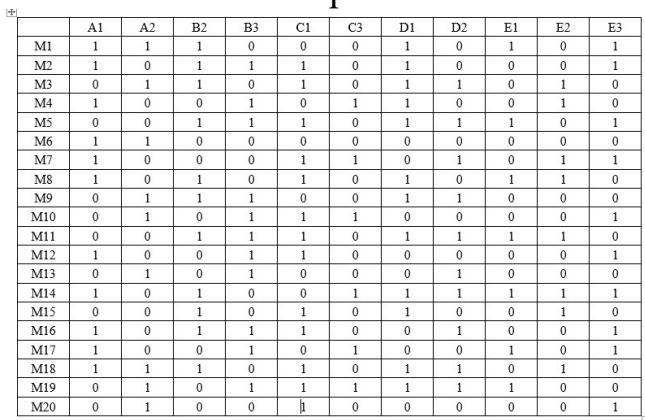

Tabel 3.3 Pembacaan pembelian pada setiap transaksi

\begin{tabular}{|l|l|}
\hline & Itemset \\
\hline M1 & $\mathrm{A} 1, \mathrm{~A} 2, \mathrm{~B} 2, \mathrm{D} 1, \mathrm{E} 1, \mathrm{E} 3$ \\
\hline M2 & $\mathrm{A} 1, \mathrm{~B} 2, \mathrm{~B} 3, \mathrm{C} 1, \mathrm{D} 1, \mathrm{E} 3$ \\
\hline $\mathrm{M} 3$ & $\mathrm{~A} 2, \mathrm{~B} 2, \mathrm{C} 1, \mathrm{D} 1, \mathrm{D} 2, \mathrm{E} 2$ \\
\hline M4 & $\mathrm{A} 1, \mathrm{~B} 3, \mathrm{C} 3, \mathrm{D} 1, \mathrm{E} 2$ \\
\hline M5 & $\mathrm{B} 2, \mathrm{~B} 3, \mathrm{C} 1, \mathrm{D} 1, \mathrm{D} 2, \mathrm{E} 1, \mathrm{E} 3$ \\
\hline M6 & $\mathrm{A} 1, \mathrm{~A} 2$ \\
\hline M7 & $\mathrm{A} 1, \mathrm{C} 1, \mathrm{C} 3, \mathrm{D} 2, \mathrm{E} 2, \mathrm{E} 3$ \\
\hline M8 & $\mathrm{A} 1, \mathrm{~B} 2, \mathrm{C} 1, \mathrm{D} 1, \mathrm{E} 1, \mathrm{E} 2$ \\
\hline M9 & $\mathrm{A} 2, \mathrm{~B} 2, \mathrm{~B} 3, \mathrm{D} 1, \mathrm{D} 2$ \\
\hline M10 & $\mathrm{A} 2, \mathrm{~B} 3, \mathrm{C} 1, \mathrm{C} 3, \mathrm{E} 3$ \\
\hline M11 & $\mathrm{B} 2, \mathrm{~B} 3, \mathrm{C} 1, \mathrm{D} 1, \mathrm{D} 2, \mathrm{E} 1, \mathrm{E} 2$ \\
\hline M12 & $\mathrm{A} 1, \mathrm{~B} 3, \mathrm{C} 1, \mathrm{E} 3$ \\
\hline M13 & $\mathrm{A} 2, \mathrm{~B} 3, \mathrm{D} 2$ \\
\hline M14 & $\mathrm{A} 1, \mathrm{~B} 2, \mathrm{C} 3, \mathrm{D} 1, \mathrm{D} 2 \mathrm{E} 1, \mathrm{E} 2, \mathrm{E} 3$ \\
\hline M15 & $\mathrm{B} 2, \mathrm{C} 1, \mathrm{D} 1, \mathrm{E} 2$ \\
\hline M16 & $\mathrm{A} 1, \mathrm{~B} 2, \mathrm{~B} 3, \mathrm{C} 1, \mathrm{D} 2, \mathrm{E} 3$ \\
\hline M17 & $\mathrm{A} 1, \mathrm{~B} 3, \mathrm{C} 3, \mathrm{E} 1, \mathrm{E} 3$ \\
\hline M18 & $\mathrm{A} 1, \mathrm{~A} 2, \mathrm{~B} 2, \mathrm{C} 1, \mathrm{D} 1, \mathrm{D} 2, \mathrm{E} 2$ \\
\hline M19 & $\mathrm{A} 2, \mathrm{~B} 3, \mathrm{C} 1, \mathrm{C} 3, \mathrm{D} 1, \mathrm{D} 2, \mathrm{E} 1$ \\
\hline M20 & $\mathrm{A} 2, \mathrm{C} 1, \mathrm{E} 3$ \\
\hline
\end{tabular}

Tabel 3.4 Kemunculan Item 


\begin{tabular}{|c|c|}
\hline Item & Jumlah \\
\hline $\mathrm{A} 1$ & 11 \\
\hline $\mathrm{A} 2$ & 9 \\
\hline $\mathrm{B} 2$ & 11 \\
\hline $\mathrm{B} 3$ & 11 \\
\hline $\mathrm{C} 1$ & 13 \\
\hline $\mathrm{C} 3$ & 6 \\
\hline $\mathrm{D} 1$ & 12 \\
\hline $\mathrm{D} 2$ & 10 \\
\hline $\mathrm{E} 1$ & 7 \\
\hline $\mathrm{E} 2$ & 8 \\
\hline $\mathrm{E} 3$ & 10 \\
\hline
\end{tabular}

\subsection{Perhitungan Algoritma FP-} Growth

Mendata kemunculan item diurut berdasarkan frekuensi tertinggi.

Tabel 3.5 Kemunculan item berdasarkan frekuensi tertinggi

\begin{tabular}{|c|c|}
\hline Item & Jumlah \\
\hline $\mathrm{C} 1$ & 13 \\
\hline $\mathrm{D} 1$ & 12 \\
\hline $\mathrm{A} 1$ & 11 \\
\hline $\mathrm{B} 2$ & 11 \\
\hline $\mathrm{B} 3$ & 11 \\
\hline $\mathrm{D} 2$ & 10 \\
\hline $\mathrm{E} 3$ & 10 \\
\hline $\mathrm{A} 2$ & 9 \\
\hline $\mathrm{E} 2$ & 8 \\
\hline $\mathrm{E} 1$ & 7 \\
\hline $\mathrm{C} 3$ & 6 \\
\hline
\end{tabular}

Setelah dilakukan Pengurutan didapat item yang memiliki frekuensi di atas support count $\geq 10$ $(30 / 108=0.27) \quad$ adalah C1,D1,A1,B2,B3,D2, dan E3. Enam itemset ini yang akan berpengaruh dan akan dimasukkan ke dalam $F P$ tree

Tabel 3.6 Kemunculan Item Pada Setiap Transaksi Berdasarkan Frequent Paling Tinggi

\begin{tabular}{|c|c|}
\hline Trans. & Item \\
\hline M1 & $\mathrm{D} 1, \mathrm{~A} 1, \mathrm{~B} 2, \mathrm{E} 3$ \\
\hline M2 & $\mathrm{C} 1, \mathrm{D} 1, \mathrm{~A} 1, \mathrm{~B} 2, \mathrm{~B} 3, \mathrm{E} 3$ \\
\hline M3 & $\mathrm{C} 1, \mathrm{D} 1, \mathrm{~B} 2, \mathrm{D} 2, \mathrm{E} 3$ \\
\hline M4 & $\mathrm{D} 1, \mathrm{~A} 1, \mathrm{~B} 3$ \\
\hline M5 & $\mathrm{C} 1, \mathrm{D} 1, \mathrm{~B} 2, \mathrm{~B} 3, \mathrm{D} 2, \mathrm{E} 3$ \\
\hline M6 & $\mathrm{A} 1$ \\
\hline M7 & $\mathrm{C} 1, \mathrm{~A} 1, \mathrm{D} 2, \mathrm{E} 3$ \\
\hline M8 & $\mathrm{C} 1, \mathrm{D} 1, \mathrm{~A} 1, \mathrm{~B} 2$ \\
\hline M9 & $\mathrm{D} 1, \mathrm{~B} 2, \mathrm{~B} 3, \mathrm{D} 2$ \\
\hline M10 & $\mathrm{C} 1, \mathrm{~B} 3, \mathrm{E} 3$ \\
\hline M11 & $\mathrm{C} 1, \mathrm{D} 1, \mathrm{~B} 2, \mathrm{~B} 3, \mathrm{D} 2$ \\
\hline M12 & $\mathrm{C} 1, \mathrm{~A} 1, \mathrm{~B} 3, \mathrm{E} 3$ \\
\hline M13 & B3,D2 \\
\hline M14 & $\mathrm{D} 1, \mathrm{~A} 1, \mathrm{~B} 2, \mathrm{D} 2, \mathrm{E} 3$ \\
\hline M15 & $\mathrm{C} 1, \mathrm{D} 1, \mathrm{~B} 2$ \\
\hline M16 & $\mathrm{C} 1, \mathrm{~A} 1, \mathrm{~B} 2, \mathrm{~B} 3, \mathrm{D} 2, \mathrm{E} 3$ \\
\hline M17 & $\mathrm{A} 1, \mathrm{~B} 3, \mathrm{E} 3$ \\
\hline M18 & $\mathrm{C} 1, \mathrm{D} 1, \mathrm{~A} 1, \mathrm{~B} 2, \mathrm{D} 2$ \\
\hline M19 & $\mathrm{C} 1, \mathrm{D} 1, \mathrm{~B} 3, \mathrm{D} 2$ \\
\hline $\mathrm{M} 2$ & $\mathrm{C} 1, \mathrm{E} 3$ \\
\hline
\end{tabular}

\subsection{Tahap Pembangunan Fp-Tree}

Dalam proses pembangunan $F P$ Tree dengan menggunakan frequent items yang telah dipangkas dan diurutkan. Data pembelian tanah liat dalam 20 (dua puluh) minggu dengan
7 jenis item (tanah liat), dipindahkan ke dalam bentuk FP-Tree setiap minggu pembelian. Setiap simpul pada FP-Tree mengandung kode item dan counter support yang berfungsi untuk menghitung frekuensi kemunculan item tersebut dalam tiap lintasan mingguan.

Item yang tidak frequent dibuang, sedangkan frequent item dimasukkan dan disusun dengan urutan menurun, seperti yang terlihat pada gambar 4.1. Berikut adalah bentuk di minggu ke-1

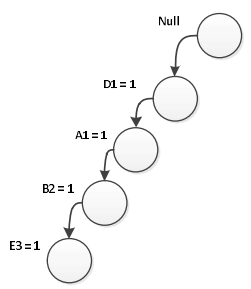

Gambar 3.1 Hasil Pembentukan FP-Tree Setelah Pembacaan M1(D1,A1,B2,E3)

Dari pembacaan pembelian pada minggu ke-1, M1 \{D1,A1,B2,E3\} maka terbentuk lintasan transaksi Null $\rightarrow \mathrm{D} 1 \rightarrow \mathrm{A} 1 \rightarrow \mathrm{B} 2 \rightarrow \mathrm{E} 3 . \quad$ Support count dari setiap simpul bernilai awal 1 (satu).

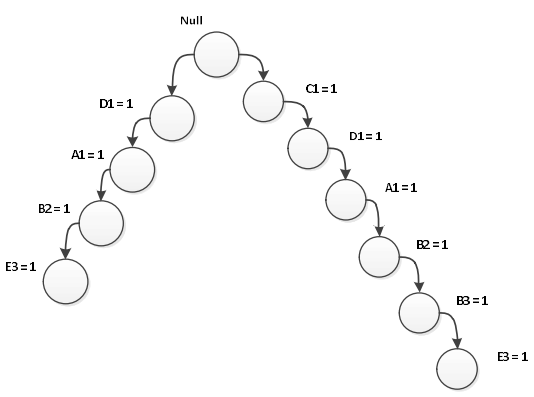

Gambar 3.2 Hasil Pembentukan FPTree Setelah Pembacaan M2 (C1,D1,A1,B2,B3,E3)

Pada pemindaian kedua pada gambar 3.2, dimana pembacaan Transaksi M2 $\{\mathrm{C} 1, \mathrm{D} 1, \mathrm{~A} 1, \mathrm{~B} 2, \mathrm{~B} 3, \mathrm{E} 3\}$ akan membuat simpul $\mathrm{C} 1, \mathrm{D} 1, \mathrm{~A} 1$, B2, B3, dan E3, sehingga terbentuk lintasan transaksi $\mathrm{Null} \rightarrow \mathrm{C} 1 \rightarrow \mathrm{D} 1 \rightarrow \mathrm{A} 1 \rightarrow \mathrm{B} 2 \rightarrow \mathrm{B} 3 \rightarrow \mathrm{E} 3$. 
Setelah dilakukan proses pembentukan FP-Tree pada transaksi M1 hingga M20, maka didapatkan bentuk Tree pada transaksi terakhir, yaitu bentuk $F P$-Tree pada transaksi minggu ke-20 (M20), sebagai berikut:

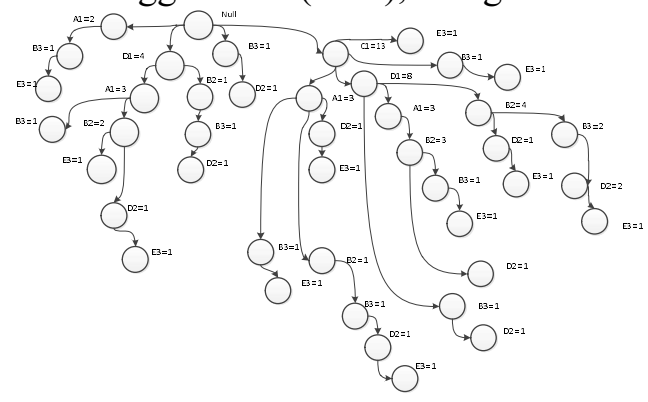

Gambar 3.3 Hasil Pembentukan FP Tree Setelah Pembacaan M20 (C1,E3)

\subsection{Tahap pencarian Frequent Itemset}

Dalam menemukan frequent itemset maka diperlukan upapohon (pohon yang akarnya adalah keturuan dari akar pohon induknya) dengan lintasan yang memiliki support count terkecil, yaitu E3. Proses pembentukannya dapat dilihat pada gambar berikut :

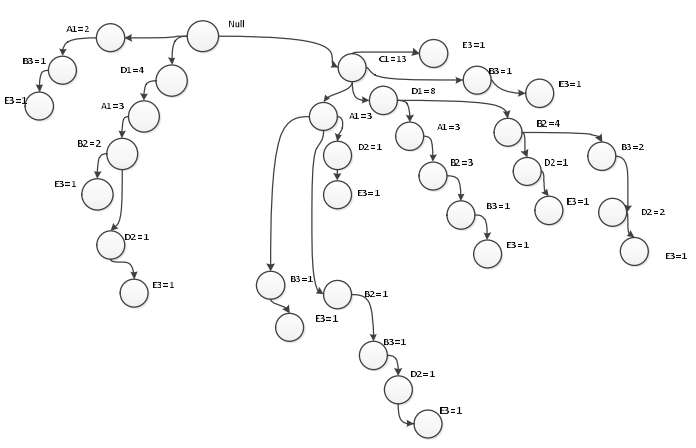

Gambar 3.3 Lintasan Yang Memiliki Nilai E3

Pada Gambar 3.3 Semua lintasan yang memiliki nilai E3 ditampilkan, lintasan yang tidak memiliki nilai E3 dihapuskan. Lintasan diambil acuan adalah $F p$-tree lengkap yang ada pada gambar 3.2

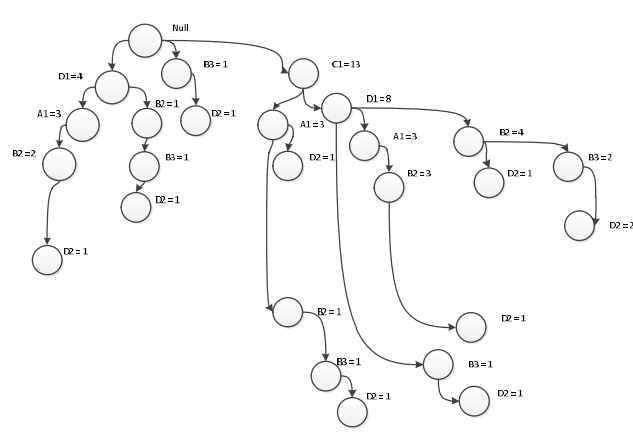

Gambar 4.22 Lintasan Yang Memiliki Nilai D2

Pada gambar 4.22 ditampilkan akar yang memiliki nilai D2.

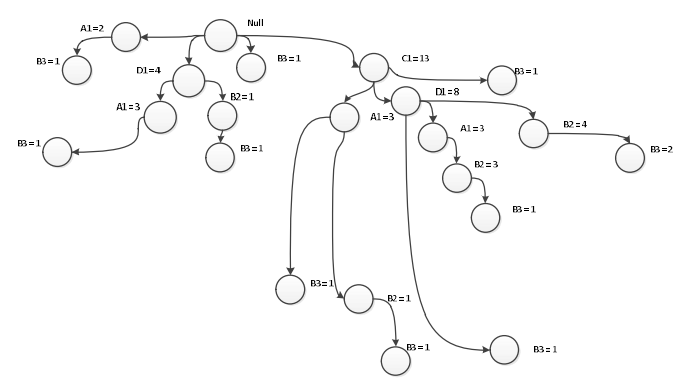

Gambar 4.23 Lintasan yang memiliki akar B3

Pada Gambar 4.23 menampilkan litasan yang memiliki akar akhir B3.

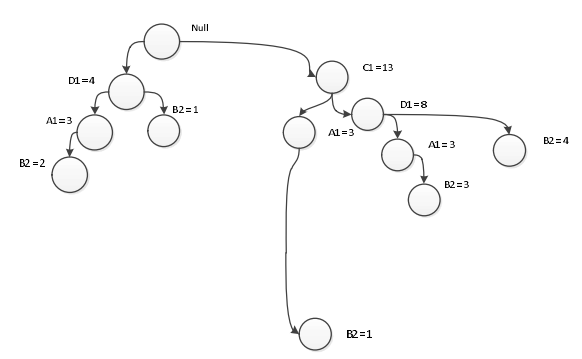

Gambar 4.24 Lintasan Yang
Memiliki B2

Pada gambar 4.24 Bentuk Lintasan B2 yang ditampilkan. 


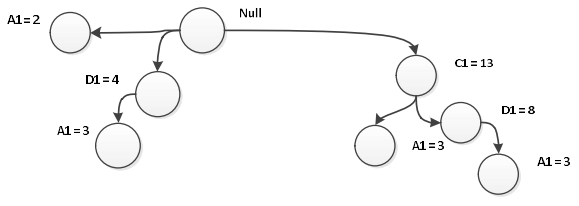

Gambar 4.25 Lintasan Yang Memiliki Nilai A1

Pada gambar 4.25 Bentuk Lintasan yang memiliki nilai A1.

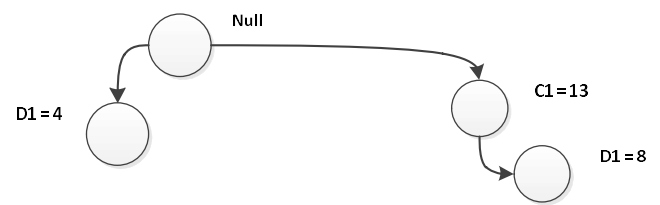

Gambar 4.26 Lintasan Yang Memiliki Nilai D1

Pada gambar 4.26 Lintasan yang memiliki nilai D1.

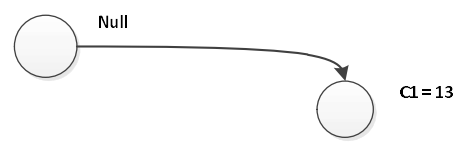

Gambar 4.27 Lintasan Yang Memiliki Nilai C1

Pada gambar 4.27 Lintasan $\mathrm{C} 1$ memiliki simpul tunggal yaitu $\mathrm{C} 1$ yang memiliki nilai support count tertinggi.

\subsection{Rule Asosiasi Algoritma FP- Growth}

Dalam menentukan Rule Asosiasi Algoritma Fp-Growth, pertama yang dilakukan adalah menemukan semua frequent itemset yang berakhiran $\mathrm{E} 3$, D2, B3, B2, A1, D1, dan C1. Lalu cek apakah support count dari E3,D2,B3,B2,A1,D1， dan C1 memenuhi minimum support count $\geq$ 10 (minimum support $\geq 0.27$ ).
Dari pembangkitan FP-tree yang telah dilakukan maka didapatkan hasil Conditional Pattern Base dan Conditional Fp-Tree sebagai berikut:

Tabel 3.7 Hasil Conditional Pattern Base dan Conditional Fp-Tree dari upapohon.

\begin{tabular}{|c|c|c|}
\hline Suffix & Conditional Pattern Base & Conditional FP-Tree \\
\hline E3 & $\begin{array}{l}\{(\mathrm{A} 1, \mathrm{~B} 3): 1,(\mathrm{D} 1, \mathrm{~A} 1, \mathrm{~B} 2): 1, \\
(\mathrm{D} 1, \mathrm{~A} 1, \mathrm{~B} 2, \mathrm{E} 3, \mathrm{D} 2): 1,(\mathrm{C} 1, \mathrm{~A} 1, \mathrm{~B} 3): 1, \\
(\mathrm{C} 1, \mathrm{~B} 3): 1,(\mathrm{C} 1, \mathrm{~A} 1, \mathrm{D} 2): 1, \\
(\mathrm{C} 1, \mathrm{~A} 1, \mathrm{~B} 2, \mathrm{~B} 3, \mathrm{D} 2): 1, \\
(\mathrm{C} 1, \mathrm{D} 1, \mathrm{~A} 1, \mathrm{~B} 2, \mathrm{~B} 3): 1, \\
(\mathrm{C} 1, \mathrm{D} 1, \mathrm{~B} 2, \mathrm{D} 2): 1, \\
(\mathrm{C} 1, \mathrm{D} 1, \mathrm{~B} 2, \mathrm{~B} 3, \mathrm{D} 2): 1\}\end{array}$ & $\begin{array}{l}\{(\mathrm{C} 1: 7, \mathrm{D} 1: 5, \mathrm{~A} 1: 7, \mathrm{~B} 2: 6, \\
\mathrm{B} 3: 6, \mathrm{D} 2: 5)\} \\
(\mathrm{C} 1, \mathrm{D} 1, \mathrm{~A} 1, \mathrm{~B} 2, \mathrm{~B} 3, \mathrm{D} 2)\end{array}$ \\
\hline D2 & $\begin{array}{l}\{(\mathrm{D} 1, \mathrm{~A} 1, \mathrm{~B} 2): 1,(\mathrm{D} 1, \mathrm{~B} 2, \mathrm{~B} 3): 1, \\
(\mathrm{C} 1, \mathrm{~A} 1): 1,(\mathrm{C} 1, \mathrm{~A} 1, \mathrm{~B} 2, \mathrm{~B} 3): 1, \\
(\mathrm{C} 1, \mathrm{D} 1, \mathrm{~B} 3),(\mathrm{C} 1, \mathrm{D} 1, \mathrm{~A} 1, \mathrm{~B} 2): 1, \\
(\mathrm{C} 1, \mathrm{D} 1, \mathrm{~B} 2): 1,(\mathrm{C} 1, \mathrm{D} 1, \mathrm{~B} 2, \mathrm{~B} 3): 2\}\end{array}$ & $\begin{array}{l}\{(\mathrm{C} 1: 7, \mathrm{D} 1: 7, \mathrm{~A} 1: 4, \mathrm{~B} 2: 6, \mathrm{~B} 3: 5)\} \\
(\mathrm{C} 1, \mathrm{D} 1, \mathrm{~A} 1, \mathrm{~B} 2, \mathrm{~B} 3)\end{array}$ \\
\hline B3 & $\begin{array}{l}\{(\mathrm{D} 1, \mathrm{~A} 1): 1,(\mathrm{D} 1, \mathrm{~B} 2): 1,(\mathrm{C} 1, \mathrm{~A} 1): 1, \\
(\mathrm{C} 1, \mathrm{~A} 1, \mathrm{~B} 2): 1,(\mathrm{C} 1, \mathrm{D} 1): 1, \\
(\mathrm{C} 1, \mathrm{D} 1, \mathrm{~A} 1, \mathrm{~B} 2): 1,(\mathrm{C} 1, \mathrm{D} 1, \mathrm{~B} 2): 2\}\end{array}$ & $\begin{array}{l}\{(\mathrm{C} 1: 6, \mathrm{D} 1: 6, \mathrm{~A} 1: 4, \mathrm{~B} 2: 5)\} \\
(\mathrm{C} 1, \mathrm{D} 1, \mathrm{~A} 1, \mathrm{~B} 2)\end{array}$ \\
\hline B2 & $\begin{array}{l}\{(\mathrm{D} 1, \mathrm{A1} 1): 2,(\mathrm{C} 1, \mathrm{~A} 1): 1, \\
(\mathrm{C} 1, \mathrm{D} 1, \mathrm{~A} 1): 3,(\mathrm{C} 1, \mathrm{D} 1): 4\}\end{array}$ & $\begin{array}{l}\{(\mathrm{C} 1: 7, \mathrm{D} 1: 9, \mathrm{~A} 1: 6)\} \\
(\mathrm{C} 1, \mathrm{D} 1, \mathrm{~A} 1)\end{array}$ \\
\hline A1 & $\{(\mathrm{C} 1, \mathrm{D} 1): 3\}$ & $\{(\mathrm{C} 1: 3, \mathrm{D} 1: 3)\}(\mathrm{C} 1, \mathrm{D} 1)$ \\
\hline D1 & $\{(\mathrm{C} 1: 8)\}(\mathrm{C} 1)$ & $\{(\mathrm{C} 1: 8)\}(\mathrm{C} 1)$ \\
\hline C1 & & \\
\hline
\end{tabular}

Dari hasil Conditional FP-Tree dan Conditional Pattern Base maka didapatkan kombinasi Frequent Itemset. Selanjutnya menghitung nilai support dan Confidence dari kombinasi Frequent Itemset.

Agar tingkat akurasi tinggi maka ditetapkan minimum Confidence $\geq 83 \%$ (0.83).

Tabel 3.8 kombinasi frequent itemset yang memenuhi Minimum Support $\geq 0.27$ dan Confidence $\geq 0.83$

\begin{tabular}{|c|c|c|c|c|}
\hline no & $\mathrm{X}$ & $\mathrm{Y}$ & Support & Confidence \\
\hline 1 & D1 & B2 & 0,5 & 0,83 \\
\hline 2 & E1 & D1 & 0,3 & 0,86 \\
\hline 3 & D1, D2 & B2 & 0,3 & 0,86 \\
\hline 4 & B2, D2 & D1 & 0,3 & 0,86 \\
\hline 5 & D1, E2 & B2 & 0,3 & 0,86 \\
\hline 6 & E2 & D1 & 0,35 & 0,88 \\
\hline 7 & C1, D1 & B2 & 0,35 & 0,88 \\
\hline 8 & C1, B2 & D1 & 0,35 & 0,88 \\
\hline 9 & B2 & D1 & 0,5 & 0,91 \\
\hline 10 & B2, E2 & D1 & 0,3 & 1,00 \\
\hline
\end{tabular}

Maka dari hasil tabel 3.8 diatas didapatkan pola Rule Asosiasi sebagai berikut:

1. [D1] --> [B2] (confidence: 0.83) Jika Perusahaan membeli tanah liat mineral tinggi dari produsen Sayang Ibu (D1) Maka Perusahaan 
juga akan membeli tanah liat mineral sedang dari produsen Bungus (B2) dengan nilai Confidence $83 \%$.

2. [E1] --> [D1] (confidence: 0.86) Jika Perusahaan membeli tanah liat mineral tinggi dari produsen Kuranji (E1) maka Perusahaan akan membeli tanah liat mineral tinggi pada produsen Sayang Ibu (D1) dengan nilai Confidence 86\%.

3. [D1, D2] --> [B2] (confidence: $0.86)$

Jika Perusahaan membeli tanah liat mineral tinggi dari produsen Sayang Ibu (D1) dan tanah liat mineral sedang dari produsen Sayang Ibu (D2) maka Perusahaan akan membeli tanah liat mineral sedang pada produsen Bungus (B2) dengan nilai Confidence $86 \%$.

4. [B2, D2] --> [D1] (confidence: $0.86)$

Jika Perusahaan membeli tanah liat mineral sedang dari produsen Bungus (B2) dan tanah liat mineral sedang dari produsen Sayang Ibu (D2) maka Perusahaan akan membeli tanah liat mineral tinggi pada produsen Sayang Ibu (D1) dengan nilai Confidence 86\%.

5. [D1, E2] --> [B2] (confidence: 0.86 )

Jika Perusahaan membeli tanah liat mineral tinggi dari produsen Sayang Ibu (D1) dan tanah liat mineral sedang dari produsen Kuranji (E2) maka Perusahaan akan membeli tanah liat mineral sedang pada produsen Bungus (B1) dengan nilai Confidence $86 \%$.

6. [E2] --> [D1] (confidence: 0.88)

Jika Perusahaan membeli tanah liat mineral sedabg dari produsen Kuranji (E2) maka Perusahaan akan membeli tanah liat mineral tinggi pada produsen Sayang Ibu (D1) dengan nilai Confidence $88 \%$.

7. [C1, D1] --> [B2] (confidence: $0.88)$

Jika Perusahaan membeli tanah liat mineral tinggi dari produsen Gunuang Sariak (C1) dan tanah liat mineral tinggi dari produsen Sayang Ibu (D1) maka Perusahaan akan membeli tanah liat mineral sedang pada produsen Bungus (B1) dengan nilai Confidence $88 \%$.

8. [C1, B2] --> [D1] (confidence: $0.88)$

Jika Perusahaan membeli tanah liat mineral tinggi dari produsen Gunung Sariak (C1) dan tanah liat mineral sedang pada produsen Bungus (B2) maka Perusahaan akan membeli tanah liat mineral tinggi pada produsen Sayang Ibu (D1) dengan nilai Confidence 88\%.

9. [B2] --> [D1] (confidence: 0.91)

Jika Perusahaan membeli tanah liat mineral sedang dari produsen bungus (B1) maka Perusahaan membeli tanah liat mineral tinggi dari produsen Sayang Ibu (D1) dengan nilai Confidence $91 \%$.

10. [B2, E2] --> [D1] (confidence: 1.00)

Jika Perusahaan membeli tanah liat mineral sedang dari produsen Bungus (B1) dan tanah liat mineral sedang dari produsen Kuranji (E2) maka Perusahaan akan membeli tanah liat mineral tinggi pada produsen Sayang Ibu (D1) dengan nilai Confidence 100\%.

\section{Kesimpulan dan Saran}

\subsection{Kesimpulan}

Dari uraian pada bab-bab yang sudah dibahas sebelumnya dapat ditarik kesimpulan :

1. Dengan Algoritma FP-Growth dapat membantu seleksi pembelian tanah liat dengan menghasilkan rule. Algoritma FP-Growth memberikan informasi ekslusif dan menggambarkan proses dalam pembelian tanah liat oleh perusahaan.

2. Penggunaan Algoritma Fp-Growth dan aplikasi software Rapidminer 7.4.0 didapatkan hasil berupa aturan (rules) yang merupakan kumpulan dari beberapa frequent itemset dengan nilai confidence yang tinggi.

3. Hasil rule dari Algoritma FP-Growth dan software Rapidminer Studio 7.4.0 membantu untuk pimpinan perusahaan membuat suatu perencanaan pembelian tanah liat. 


\subsection{Saran}

Dalam implementasi Algoritma FPGrowth dalam membuat rule atau aturan untuk pengambilan keputusan belanja sangat membantu bagi perusahaan. Berikut adalah saran yang dapat diperhatikan untuk masa yang akan datang.

1. Implementasi Algoritma FPGrowth sangat praktis namun harus dilakukan perbandingan dengan Algoritma lain, sebagai bahan penguji sejauh mana Algoritma FP-Growth dapat diandalkan dalam pengambilan keputusan dan pembuatan aturan.

2. Penerapan Algoritma Fp-Growth sangat tergantung pada penentuan minimum support, semakin besar minimum support-nya maka semakin besar pula performance dari Algoritma-nya. Begitupun sebaliknya.

3. Dalam penambangan data, sebaiknya ditambahkan jumlah transaksi yang lebih banyak, agar rule yang dihasilkan lebih akurat.

\section{Daftar Pustaka}

Aggarwal, S., \& Kaur, R. (2013). Comparative Study of Various Improved Versions of Apriori Algorithm. International Journal of Engineering Trends and Technology (IJETT), 4(41), 687-690.

Angeline, D. Magdalene, D. (2013). Association Rule Generation for Student Performance Analysis using Apriori Algorithm. The SIJ Transactions on Computer Science Engineering \& Its Applications (CSEA), 1(1), p12--16.

Defit, S. (2013). Penggunaan Algorithma Apriori Dalam Menganalisa Prilaku Mahasiswa Dalam Memilih Mata Kuliah ( Studi Kasus: Fkip Upi “ Yptk”), 8(3), 31-42.

Gunadi, G., \& Sensuse, D. I. (2012). Penerapan Metode Data Mining Market Basket Analysis Terhadap Data Penjualan Produk Buku Dengan Menggunakan Algoritma Apriori Dan Frequent Pattern Growth ( FpGrowth ): Telematika, 4(1), 118132.
Ikhwan, A., Nofriansyah, D., \& Sriani. (2015). Penerapan Data Mining dengan Algoritma Fp-Growth untuk Mendukung Strategi Promosi Pendidikan ( Studi Kasus Kampus STMIK Triguna Dharma ). Saintikom, 14(3), 211-226.

Jiawei, H., Kamber, M., \& Pei, J. (2012). Data Mining: Concepts and Techniques. San Francisco, CA, itd: Morgan Kaufmann. https://doi.org/10.1016/B978-0-12381479-1.00001-0

Kurniawati, A. (2014). Pemetaan Pola Hubungan Program Studi Dengan Algoritma Apriori Studi Kasus SPMU UNNES. EDUKOM, 1(1), 51-58.

Obaje, S. O., Omada, J. I., \& Dambatta, U. A. (2013). Clays and their Industrial Applications: Synoptic Review. International Journal of Science and Technology, 3(5), 264270.

Ririanti. (2014). Implementasi Algoritma Fp-Growth Pada Aplikasi Prediksi Persediaan Sepeda Motor ( Studi Kasus Pt . Pilar Deli Labumas ). Pelia Informatika Budi Darma, VI(1), 139144.

Sari, E. N. (2013). Analisa Algoritma Apriori Untuk Menentukan Merek Pakaian Yang Paling Diminati Pada Mode Fashion Group Medan. Jurnal Teknik Informatika, IV, 35-39.

Sidhu, S. (2014). FP Growth Algorithm Implementation, 93(8), 6-10.

Singh, J., \& Ram, H. (2013). Improving efficiency of Apriori algorithm using transaction reduction. International Journal of Scientific and Research Publications, 3(1), 1-4.

Suresh, J., Rushyanth, P., \& Trinath, C. (2013). Generating associations rule mining using Apriori and FPGrowth Algorithms. International Journal of Computer Trends and Technology, 4(4), 887-892.

Tampubolon, K., Saragih, H., Reza, (2013). Implementasi Data Mining Algoritma Apriori Pada Sistem Persediaan Alat-Alat Kesehatan. Informasi Dan Teknologi Ilmiah, 93106. 